\title{
Pharmacophore Hybridization To Discover Novel Topoisomerase II Poisons with Promising Antiproliferative Activity
}

\author{
Jose Antonio Ortega, ${ }^{\dagger, \perp}$ Laura Riccardi, ${ }^{\dagger, \perp}$ Elirosa Minniti, ${ }^{\dagger, \S}$ Marco Borgogno, ${ }^{\dagger}$ Jose M. Arencibia, ${ }^{\dagger}(0)$

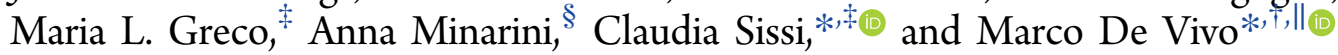 \\ ${ }^{\dagger}$ Laboratory of Molecular Modeling and Drug Discovery, Istituto Italiano di Tecnologia, Via Morego 30, 16163 Genova, Italy \\ "Department of Pharmaceutical and Pharmacological Sciences, University of Padova, Via Marzolo 5, 35131 Padova, Italy \\ ${ }^{\S}$ Department of Pharmacy and Biotechnology, Alma Mater Studiorum-University of Bologna, Via Belmeloro 6, 40126 Bologna, Italy \\ "IAS-5/INM-9 Computational Biomedicine Forschungszentrum Jülich, Wilhelm-Johnen-Straße, 52428 Jülich, Germany
}

\section{Supporting Information}

\begin{abstract}
We used a pharmacophore hybridization strategy to combine key structural elements of merbarone and etoposide and generated new type II topoisomerase (topoII) poisons. This first set of hybrid topoII poisons shows promising antiproliferative activity on human cancer cells, endorsing their further exploration for anticancer drug discovery.
\end{abstract}

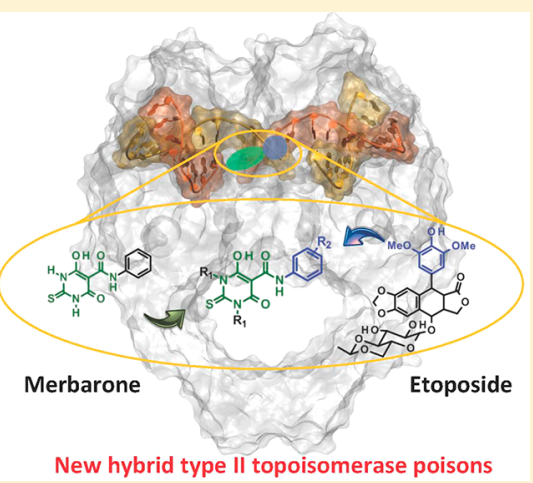

\section{INTRODUCTION}

Human type II topoisomerase (topoII) enzymes are essential for DNA topology modification and are a validated anticancer drug target. ${ }^{1-3}$ Several topoII inhibitors are clinically available, but drug resistance and the severe side effects of topoII-targeted drugs are an issue. Novel and safer topoII inhibitors for better anticancer therapeutics are thus required. ${ }^{4-6}$

TopoII inhibitors are divided into different classes according to their chemical scaffold or their molecular mechanism of action. $^{7-10}$ "TopoII poisons" is the term for topoII targeted agents that act by trapping the covalent topoII/DNA cleavage complex, which is formed during the catalytic cycle required for DNA topology modulation. One notable topoII poison is the chemotherapy drug etoposide (Figure 1). It was the first successful anticancer agent to target topoII and is still used to treat a variety of cancer types, despite the chances of severe side effects. ${ }^{4,11}$

Merbarone is another well-known topoII blocker and one of the first and most promising topoII inhibitors (Figure 1). ${ }^{12}$ Merbarone is a thiobarbituric derivative (6-hydroxy-4-oxo- $N$ phenyl-2-thioxo- $1 \mathrm{H}$-pyrimidine-5-carboxamide) that impairs cell cycle and proliferation of different cancer cell lines. ${ }^{12}$ Merbarone underwent clinical trials as a treatment for various types of cancer. ${ }^{13,14}$ However, these trials were halted due to insufficient anticancer activity and nephrotoxicity issues. ${ }^{15}$ That is, this promising anticancer chemical scaffold did not generate the expected efficacy in vivo.

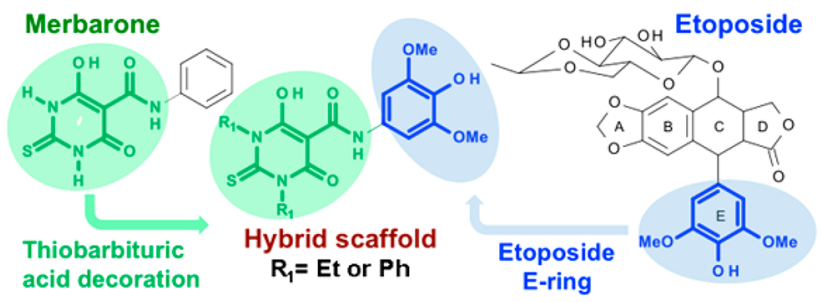

Figure 1. TopoII poisons designed via a pharmacophore hybridization strategy. The new hybrid functional scaffold (center) is obtained by merging merbarone's thiobarbituric core, with different decorations of the two heterocycle nitrogen atoms (left) and with the E-ring of etoposide (right).

\section{RESULTS AND DISCUSSION}

Here, we report on the design, synthesis, and initial biological evaluation of a first set of new compounds designed via a pharmacophore hybridization strategy. ${ }^{16,17}$ Specifically, we introduced key pharmacophoric elements of etoposide (Ering $)^{11}$ and merbarone (thiobarbituric core $)^{12}$ into a new hybrid scaffold (Figure 1). Importantly, compared to the template compounds, our new compounds show boosted potency in blocking topoII function and promising antiproliferative activity against human cancer cells.

Received: September 19, 2017

Published: October 27, 2017 
In detail, these new hybrid molecules were generated based on merbarone's thiobarbituric core, which was modified as follows: (1) introduction of two ethyl groups or phenyl rings at each nitrogen of the thiobarbituric core, where lipophilic substituents at those nitrogen atoms have been shown to improve merbarone's cell permeability; ${ }^{18-20}$ (2) functionalization of the phenyl ring in merbarone to mimic the pendent aromatic ring (E-ring) of etoposide, which was demonstrated to be essential to block topoII activity. ${ }^{11}$ This modification was planned to fine-tune the drug-target interactions at the topoII/ DNA cleavage complex, as suggested by molecular docking (see data below and in Supporting Information). The resulting hybrid scaffold was synthesized using a general procedure for amide derivatives synthesis (Scheme 1 ). ${ }^{21}$ We thus obtained 16 new hybrid compounds with different functionalizations (see Supporting Information for complete list).

Scheme 1. 2-Thiobarbituric Acid Derivatives Synthesis ${ }^{a}$

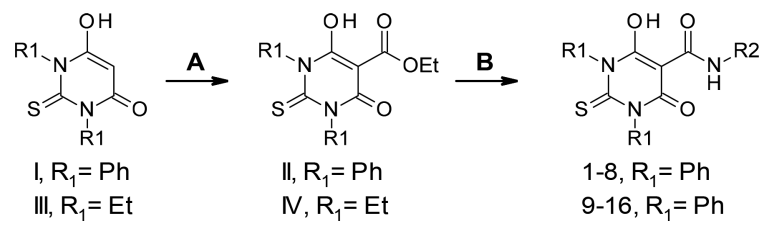

${ }^{a}$ (A) Ethyl chloroformate (1.05 equiv), DMAP (0.08 equiv), pyridine (1.25 equiv), DCM, $\mathrm{N}_{2}, 0{ }^{\circ} \mathrm{C}$ to rt, $16 \mathrm{~h}$, yield II $71 \%$, yield IV $60 \%$; (B) $\mathrm{R}_{2}-\mathrm{NH}_{2}$ (1 equiv), DMF, $\mathrm{N}_{2}, 100{ }^{\circ} \mathrm{C}, 30 \mathrm{~min}$.

Initially, all compounds were tested against human topoII in a relaxation inhibition assay (see Supporting Information). The $N, N^{\prime}$-diphenyl derivatives $(\mathbf{1}-\mathbf{8})$ were consistently much more active than the corresponding diethyl ones (9-16; see Supporting Information). Table 1 reports the $\mathrm{IC}_{50}$ values for the most active $N, N^{\prime}$-diphenyl derivatives (1-5, Scheme 1; see Supporting Information for 6-16). The improved activity of our $N, N^{\prime}$-diphenyl (vs $N, N^{\prime}$-diethyl) derivatives can be rationalized by their predicted binding mode at the cleavage site. Indeed, molecular modeling and docking ${ }^{22,23}$ showed that $N, N^{\prime}$-diphenyl derivatives formed good contacts with topoII residues located in front of both DNA grooves (Asp479 and
Arg503, more on this below). Thus, compared to the corresponding diethyl derivatives, $N, N^{\prime}$-diphenyl derivatives likely act as a better linker between distal topoII/DNA structural elements, mimicking etoposide's binding mode (see Supporting Information). This is further corroborated by the experimentally measured cleavage product formation, which was only generated by $N, N^{\prime}$-diphenyl derivatives (see Table 1 and Supporting Information).

Compound 1, which bears a 3,5-dimethoxy-4-phenol fragment (like the E-ring in etoposide), was equipotent to merbarone (Table 1), with an $\mathrm{IC}_{50}$ of $120 \mu \mathrm{M}$. Replacing the hydroxyl group of 1 with a methoxy lead to a complete loss of activity (compound 6; see Supporting Information). An equally negative effect was observed when the same hydroxyl group in 1 was removed (compound 7; see Supporting Information). Compound 2, in which the two methoxy groups were removed, was slightly worse than 1 , with an $\mathrm{IC}_{50}$ of $150 \mu \mathrm{M}$. These results are in agreement with previous studies that demonstrate the crucial role of the etoposide E-ring substituents for topoII inhibition. $^{24,25}$

Interestingly, conserving only one methoxy group in the meta position, as in 3 , returned an $\mathrm{IC}_{50}$ of $30 \mu \mathrm{M}$, with a 4 -fold increase of potency compared to merbarone and etoposide. Replacing this methoxy in 3 with a hydroxyl group, as in 4, significantly decreased topoII inhibitory activity $\left(\mathrm{IC}_{50}=200\right.$ $\mu \mathrm{M})$. Finally, a naked phenyl ring, as in $\mathbf{5}$, showed an $\mathrm{IC}_{50}$ of 5 $\mu \mathrm{M}$, which is 24 -fold better than merbarone and etoposide, although the topoII/DNA cleavage complex formation was reduced (see below).

The molecular mechanisms leading to the topoII inhibition by the five most active compounds, 1-5, were further characterized (see Table 1). UV measurements showed that DNA alone does not produce variations of the ligand absorbance induced by DNA. This suggests a lack of relevant binding of all our new derivatives to the DNA alone. Consistently, as already observed with merbarone, ${ }^{12,26} \mathrm{CD}$ titration of ctDNA with the compounds presented in this work showed their inability to alter DNA structural arrangement in the absence of topoII. As a consequence, this excludes an interference in the DNA-topoII ligation step as a mechanism of inhibition. Intriguingly, these $N, N^{\prime}$-diphenyl derivatives

Table 1. Data on Compound Potency and Properties

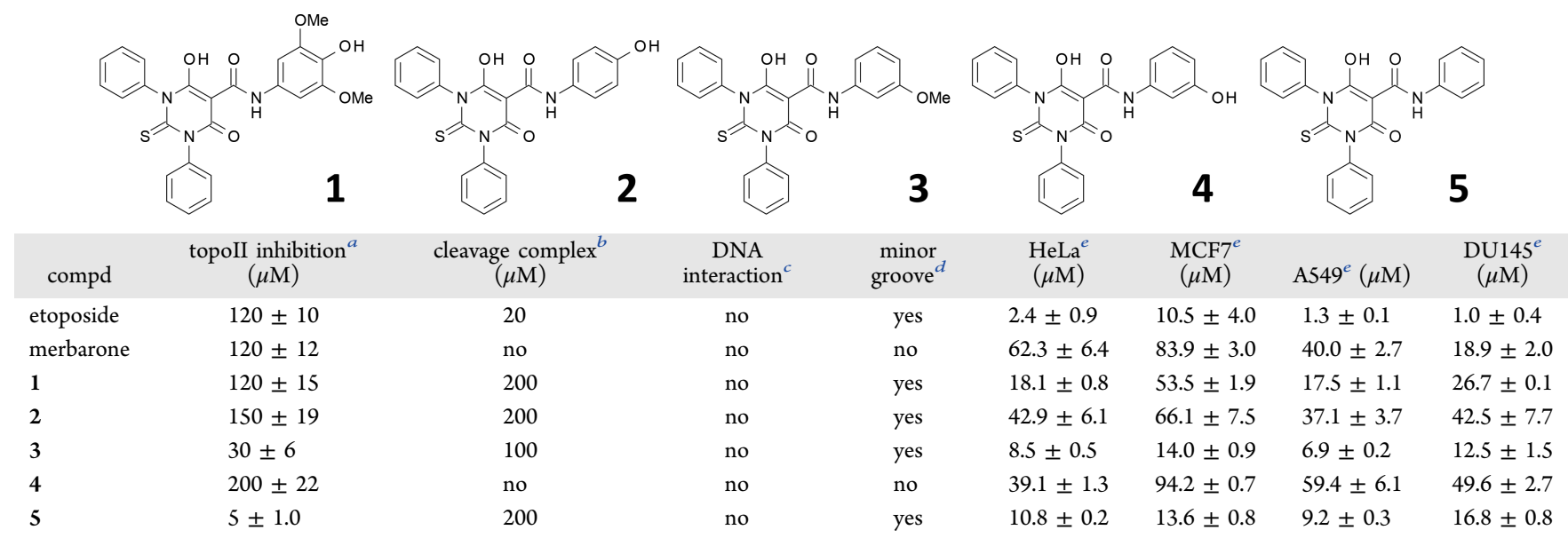

${ }^{a} \mathrm{IC}_{50}$ values. ${ }^{b}$ Compound concentration necessary to observe the same amount of topoII/DNA cleavage complex generated by etoposide at $20 \mu \mathrm{M}$. ${ }^{c}$ Interaction with DNA in absence of topoII enzyme. ${ }^{d}$ Extension of the functionalized group of the hybrid compound to the DNA minor groove, compared to the E-ring of etoposide. ${ }^{e}$ Antiproliferative activity for each cellular line. 
seemed to act differently than merbarone while behaving similarly to etoposide. In fact, while merbarone is not a poison, ${ }^{12,26}$ some compounds in the present work containing merbarone's thiobarbituric core showed the ability to stabilize the topoII/DNA cleavage complex, thus acting as a poison. This was demonstrated by cleavage assay with 1-3 and 5, which showed the presence of linear DNA, although to a lesser extent than etoposide (see Table 1 and Figure S5 in Supporting Information) as a consequence of cleavable complex stabilization. Notably, this evidence sustains our docking calculations at the etoposide binding site. ${ }^{1,23}$ In contrast, 4 's poor potency in blocking topoII was reflected in its inability to generate the topoII/DNA cleavage complex.

Thus, our experimental findings indicate that 1-3 and 5 act by poisoning the topoII/DNA cleavage complex, similar to etoposide. In addition, our docking calculations further support the hypothesis that our active hybrid topoII poisons may favor the formation of a stable topoII/DNA cleavage complex. Indeed, our docking results suggest key interactions between the $N, N^{\prime}$-diphenyl derivatives and the topoII/DNA complex. In particular, 1 is predicted to have a binding mode very similar to that of etoposide (Figure 2), with its 3,5-dimethoxy-4-phenol

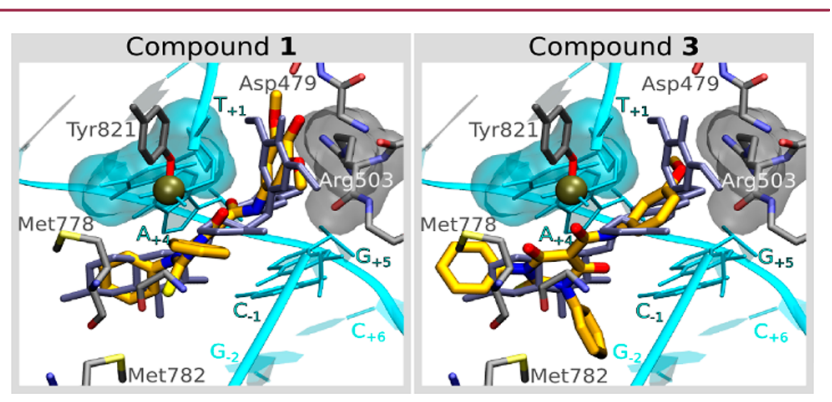

Figure 2. Docking of 1 and 3 (yellow) in the topoII (gray)/DNA (cyan) cleavage complex and their superposition to the crystal pose of etoposide (PDB code $3 \mathrm{QX} 3)^{11}$ (all $N, N^{\prime}$-diphenyl derivatives in Supporting Information).

ring forming an H-bond with Asp479. Also, one of the two unsubstituted phenyl rings of $\mathbf{1}$ was extended toward the binding site that is occupied by the glycosidic moiety of etoposide (Figure 2). ${ }^{11}$ The other phenyl ring overlapped with the D-ring of etoposide, thus closer to the scissile phosphate of the $\mathrm{T}_{+1}$ nucleotide along the cleaved DNA strand (Figure 2). Interestingly, this binding mode of the two naked phenyl rings was conserved in $\mathbf{4}$ and $\mathbf{5}$, too. However, the 3-phenol ring of $\mathbf{4}$ interacted with the side chain of Arg503, pointing its hydroxyl group toward the DNA backbone. For this reason, the binding pose of 4 did not allow an extension of the 3-phenol ring into the DNA minor groove, as shown for 1-3 and 5. This may explain 4's inability to stabilize the topoII/DNA cleavage complex.

Moreover, the two naked phenyl rings of 3 protruded into the DNA major groove, in front of the $T_{+1} / A_{+4}$ and $C_{-1} / G_{+5}$ base pairs, interacting with the side chains of Met782 and Met778. In this way, the methoxy group of 3 was between the side chain of Arg503 and the deoxyribose of the $T_{+1}$ nucleotide (Figure 2). Thus, the methoxy group forms key topoII/DNA interactions in 3, likely explaining its slightly higher ability to form topoII/DNA cleavage complex (100 $\mu \mathrm{M}$ for 3 vs $200 \mu \mathrm{M}$ for all the other new compounds). Notably, the relevance of this methoxy group is well-known for etoposide, where its removal leads to a significant loss of activity. ${ }^{11,24,25}$
Finally, we evaluated the antiproliferative activity of these compounds in human endometrial (HeLa), breast (MCF7), lung (A549), and androgen-independent prostate (DU145) cancer cell lines. Overall, we found a general improvement of the antiproliferative activity of these new compounds compared to merbarone, with an increase in potency, up to 6-fold in HeLa, MCF7, and A549 cell lines. These compounds were also slightly more potent than merbarone in DU145 cells (Table 1). Compared to etoposide, they were equipotent (MCF7) or slightly less active (HeLa, A549, and DU145). Notably, we also observed an increase in $\mathrm{H} 2 \mathrm{AX}$ phosphorylation after treatment of HeLa cells with 5 (Figure S7), ${ }^{27}$ which indicates that the cytotoxicity observed is likely caused by cellular inhibition of topoII.

\section{CONCLUSION}

In summary, we present new human topoII poisons obtained by merging, into a single new hybrid functional scaffold, key pharmacophoric elements of etoposide and merbarone. Importantly, we obtained new compounds that are significantly active in blocking topoII function, including when compared to the two template structures. These new hybrid molecules show promising antiproliferative activity against human cancer cells. Thus, taken together, these results endorse a further exploration of this first set of new hybrid compounds to better characterize their mechanism of action and their overall potential as novel anticancer therapeutics.

\section{EXPERIMENTAL SECTION}

General Considerations. All the commercial available reagents and solvents were used as purchased from vendors without further purification. Dry solvents were purchased from Sigma-Aldrich. Automated column chromatography purifications were done using a Teledyne ISCO apparatus (CombiFlash Rf) with prepacked silica gel columns of different sizes (from $4 \mathrm{~g}$ up to $24 \mathrm{~g}$ ) and mixtures of increasing polarity of cyclohexane and ethyl acetate (EtOAc) or dichloromethane (DCM) and methanol $(\mathrm{MeOH})$. NMR experiments were run on a Bruker Avance III 400 system $\left(400.13 \mathrm{MHz}\right.$ for ${ }^{1} \mathrm{H}$, and $100.62 \mathrm{MHz}$ for ${ }^{13} \mathrm{C}$ ), equipped with a BBI probe and Z-gradients. Spectra were acquired at $300 \mathrm{~K}$, using deuterated dimethylsulfoxide $\left(\mathrm{DMSO}-d_{6}\right)$ or deuterated chloroform $\left(\mathrm{CDCl}_{3}\right)$ as solvents. For ${ }^{1} \mathrm{H}$ $\mathrm{NMR}$, data are reported as follows: chemical shift, multiplicity $(\mathrm{s}=$ singlet, $\mathrm{d}=$ doublet, $\mathrm{dd}=$ double of doublets, $\mathrm{t}=$ triplet, $\mathrm{q}=$ quartet, $\mathrm{m}$ $=$ multiplet), coupling constants $(\mathrm{Hz})$, and integration. UPLC/MS analyses were run on a Waters ACQUITY UPLC/MS system consisting of a SQD (single quadrupole detector) mass spectrometer equipped with an electrospray ionization interface and a photodiode array detector. The PDA range was $210-400 \mathrm{~nm}$. Analyses were performed on an ACQUITY UPLC BEH C18 column $(100 \mathrm{~mm} \times 2.1$ $\mathrm{mm}$ i.d., particle size $1.7 \mu \mathrm{m}$ ) with a VanGuard BEH C18 precolumn $(5 \mathrm{~mm} \times 2.1 \mathrm{~mm}$ i.d., particle size $1.7 \mu \mathrm{m})$. Mobile phase was $10 \mathrm{mM}$ $\mathrm{NH}_{4} \mathrm{OAc}$ in $\mathrm{H}_{2} \mathrm{O}$ at $\mathrm{pH} 5$ adjusted with $\mathrm{CH}_{3} \mathrm{COOH}$ (A) and $10 \mathrm{mM}$ $\mathrm{NH}_{4} \mathrm{OAc}$ in $\mathrm{CH}_{3} \mathrm{CN}-\mathrm{H}_{2} \mathrm{O}$ (95:5) at $\mathrm{pH}$ 5.0. The mobile-phase $\mathrm{B}$ proportion increased from $10 \%$ to $90 \%$ in $6.5 \mathrm{~min}$ with a $0.5 \mathrm{~mL} / \mathrm{min}$ flow rate. Electrospray ionization in positive and negative mode was applied. All tested compounds showed $\geq 95 \%$ purity by NMR and UPLC/MS analysis.

4-Hydroxy- $\mathrm{N}$-(4-hydroxy-3,5-dimethoxyphenyl)-6-oxo-1,3diphenyl-2-thioxopyrimidine-5-carboxamide (1). The title compound was synthesized following general procedure B (see Supporting Information) using compound II (200 $\mathrm{mg}, 0.51 \mathrm{mmol}$ ) and 4-amino2,6-dimethoxyphenol $(63.8 \mathrm{mg}, 0.51 \mathrm{mmol})$, obtaining $15.7 \mathrm{mg}$ of pure compound (yield 16\%). Synthesis of the intermediates II and 4amino-2,6-dimethoxyphenol are in the Supporting Information. $t_{\mathrm{R}}=$ 1.96 min. MS (SI) $m / z: 492.1[\mathrm{M}-\mathrm{H}]^{+},[\mathrm{M}-\mathrm{H}]^{+}$; calculated, 492.1 . ${ }^{1} \mathrm{H}$ NMR (400 MHz, $\left.\mathrm{CDCl}_{3}\right): 11.82(\mathrm{~s}, 1 \mathrm{H}), 7.58-7.47$ (m, 6H), 7.31 
$(\mathrm{dd}, J=7.4,3.1 \mathrm{~Hz}, 4 \mathrm{H}), 6.76(\mathrm{~s}, 2 \mathrm{H}), 5.47(\mathrm{~s}, 1 \mathrm{H}), 3.86(\mathrm{~s}, 6 \mathrm{H}) .{ }^{13} \mathrm{C}$ NMR (101 MHz, $\left.\mathrm{CDCl}_{3}\right) \delta 178.59(\mathrm{CONH}), 168.63(\mathrm{CS}), 162.39$ (C), 147.22 (C), 139.26 (C), 138.16 (C), 137.04 (C), 133.42 (C), $129.87(\mathrm{CH}), 129.76(\mathrm{CH}), 129.36(\mathrm{CH}), 129.15(\mathrm{CH}), 128.77$ $(\mathrm{CH}), 128.63(\mathrm{CH}), 127.34(\mathrm{CH}), 99.60(\mathrm{CH}), 56.59(\mathrm{OCH} 3)$. qNMR: $95.3 \%$.

4-Hydroxy- $\mathrm{N}$-(4-hydroxyphenyl)-6-oxo-1,3-diphenyl-2thioxopyrimidine-5-carboxamide (2). The title compound was synthesized following general procedure B (see Supporting Information) using II (100 mg, $0.27 \mathrm{mmol})$ and 4-aminophenol (30.0 mg, 0.27 $\mathrm{mmol}$ ), obtaining $25.1 \mathrm{mg}$ of pure compound (yield $22 \%$ ). $t_{\mathrm{R}}=2.10$ $\min$. MS (SI) $m / z: 432.1[\mathrm{M}-\mathrm{H}]^{-}$; $[\mathrm{M}-\mathrm{H}]^{-}$calculated, $432,1 .{ }^{1} \mathrm{H}$ NMR (400 MHz, DMSO-d 6 ) $\delta 11.49(\mathrm{~s}, 1 \mathrm{H}), 9.64(\mathrm{~s}, 1 \mathrm{H}), 7.48(\mathrm{t}, \mathrm{J}=$ $7.5 \mathrm{~Hz}, 4 \mathrm{H}), 7.40(\mathrm{t}, J=7.3 \mathrm{~Hz}, 2 \mathrm{H}), 7.34-7.32(\mathrm{~m}, \mathrm{~J}=8.2,3.2 \mathrm{~Hz}$, $6 \mathrm{H}), 6.78(\mathrm{~d}, J=8.8 \mathrm{~Hz}, 2 \mathrm{H}) .{ }^{13} \mathrm{C}$ NMR $\left(101 \mathrm{MHz}\right.$, DMSO- $\left.d_{6}\right) \delta$ 178.40 (CS), 168.12 (CONH), 155.76 (C), 139.19 (C), $129.16(\mathrm{CH})$, $128.98(\mathrm{CH}), 128.39(\mathrm{CH}), 124.02(\mathrm{CH}), 115.69(\mathrm{CH}), 83.59(\mathrm{C})$. qNMR: $95.0 \%$.

4-Hydroxy-N-(3-methoxyphenyl)-6-oxo-1,3-diphenyl-2thioxopyrimidine-5-carboxamide (3). The title compound was synthesized following general procedure B (see Supporting Information) using II (100 mg, $0.27 \mathrm{mmol})$ and $m$-anisidine $(0.031 \mathrm{~mL}, 0.27$ $\mathrm{mmol}$ ), obtaining $66.1 \mathrm{mg}$ of pure compound (yield $55 \%$ ). $t_{\mathrm{R}}=2.10$ $\min$. MS (SI) $m / z: 446.1[\mathrm{M}-\mathrm{H}]^{+} ;[\mathrm{M}-\mathrm{H}]^{+}$calculated, $446,1 .{ }^{1} \mathrm{H}$ NMR $\left(400 \mathrm{MHz}, \mathrm{CDCl}_{3}\right) \delta 11.85(\mathrm{~s}, 1 \mathrm{H}), 7.62-7.52(\mathrm{~m}, 4 \mathrm{H}), 7.52-$ $7.45(\mathrm{~m}, 2 \mathrm{H}), 7.40-7.28(\mathrm{~m}, 4 \mathrm{H}), 7.27(\mathrm{~d}, J=4.4 \mathrm{~Hz}, 2 \mathrm{H}), 7.13-7.01$ $(\mathrm{m}, 2 \mathrm{H}), 6.78(\mathrm{dd}, J=8.2,2.4 \mathrm{~Hz}, 1 \mathrm{H}), 3.79(\mathrm{~s}, 3 \mathrm{H}) .{ }^{13} \mathrm{C}$ NMR $(101$ $\left.\mathrm{MHz}, \mathrm{CDCl}_{3}\right) \delta 169.33(\mathrm{CONH}), 167.83(\mathrm{C}), 160.36(\mathrm{C}), 139.22$ (C), $136.31(\mathrm{C}), 130.26(\mathrm{CH}), 129.87(\mathrm{CH}), 129.77(\mathrm{CH}), 129.38$ $(\mathrm{CH}), 129.14(\mathrm{CH}), 128.75(\mathrm{CH}), 128.63(\mathrm{CH}), 114.25(\mathrm{CH})$, $112.31(\mathrm{CH}), 107.77(\mathrm{CH}), 83.65(\mathrm{C}), 55.57\left(\mathrm{OCH}_{3}\right)$. qNMR: $96.1 \%$.

4-Hydroxy- $\mathrm{N}$-(3-hydroxyphenyl)-6-oxo-1,3-diphenyl-2thioxopyrimidine-5-carboxamide (4). The title compound was synthesized following general procedure B (see Supporting Information) using II (100 mg, $0.27 \mathrm{mmol})$ and 3-aminophenol (30 mg, 0.27 $\mathrm{mmol}$ ), obtaining $29.6 \mathrm{mg}$ of pure compound (yield $26 \%$ ). $t_{\mathrm{R}}=1.84$ $\min$. MS (SI) $m / z: 432.3[\mathrm{M}-\mathrm{H}]^{-}$; $[\mathrm{M}-\mathrm{H}]^{-}$calculated, 432.1. ${ }^{1} \mathrm{H}$ NMR $\left(400 \mathrm{MHz}, \mathrm{CDCl}_{3}\right) \delta 11.84(\mathrm{~s}, 1 \mathrm{H}), 7.68-7.43(\mathrm{~m}, 6 \mathrm{H}), 7.33$ $(\mathrm{t}, J=6.9 \mathrm{~Hz}, 4 \mathrm{H}), 7.24(\mathrm{t}, J=8.1 \mathrm{~Hz}, 1 \mathrm{H}), 7.13(\mathrm{~s}, 1 \mathrm{H}), 6.98(\mathrm{~d}, \mathrm{~J}=$ $8.0 \mathrm{~Hz}, 1 \mathrm{H}), 6.76-6.68(\mathrm{~m}, 1 \mathrm{H}), 5.08(\mathrm{~s}, 1 \mathrm{H}) .{ }^{13} \mathrm{C} \mathrm{NMR}(101 \mathrm{MHz}$, $\left.\mathrm{CDCl}_{3}\right) \delta 178.29(\mathrm{CS}), 169.02(\mathrm{CONH}), 167.55(\mathrm{C}), 161.96(\mathrm{C})$, 156.07 (C), 138.87 (C), 137.76 (C), $136.13(\mathrm{C}), 130.15(\mathrm{CH}), 129.56$ $(\mathrm{CH}), 129.47(\mathrm{CH}), 129.09(\mathrm{CH}), 128.84(\mathrm{CH}), 128.43(\mathrm{CH})$, $128.31(\mathrm{CH}), 113.96(\mathrm{CH}), 113.24(\mathrm{CH}), 108.90(\mathrm{CH}), 83.38(\mathrm{C})$. qNMR: $95.1 \%$.

4-Hydroxy-6-oxo-N,1,3-triphenyl-2-thioxopyrimidine-5-carboxamide (5). The title compound was synthesized following general procedure B (see Supporting Information) using II (100 mg, 0.27 mmol) and aniline $(25 \mu \mathrm{L}, 0.37 \mathrm{mmol})$, obtaining $118.4 \mathrm{mg}$ of pure compound (yield 86\%). $t_{\mathrm{R}}=2.19 \mathrm{~min}$. MS (SI) $\mathrm{m} / z: 414.1[\mathrm{M}-\mathrm{H}]^{-}$; $[\mathrm{M}-\mathrm{H}]^{-}$calculated, 414.1. ${ }^{1} \mathrm{H}$ NMR (400 MHz, DMSO-d 6 ) $\delta 11.65$ (s, $1 \mathrm{H}), 7.57-7.51(\mathrm{~m}, 2 \mathrm{H}), 7.50-7.46(\mathrm{~m}, J=7.6 \mathrm{~Hz}, 3 \mathrm{H}), 7.43-$ $7.37(\mathrm{~m}, J=7.3 \mathrm{~Hz}, 4 \mathrm{H}), 7.36-7.31(\mathrm{~m}, \mathrm{~J}=7.8 \mathrm{~Hz}, 4 \mathrm{H}), 7.24(\mathrm{t}, J=$ $7.4 \mathrm{~Hz}, 1 \mathrm{H}) .{ }^{13} \mathrm{C} \mathrm{NMR}\left(101 \mathrm{MHz}, \mathrm{CDCl}_{3}\right) \delta 178.67(\mathrm{CONH})$, 169.32 (CS), 167.82 (COH), 162.32 (CO), $139.22(\mathrm{C}), 138.14(\mathrm{C})$, $135.21(\mathrm{C}), 129.88(\mathrm{CH}), 129.79(\mathrm{CH}), 129.51(\mathrm{CH}), 129.39(\mathrm{CH})$, $129.15(\mathrm{CH}), 128.75(\mathrm{CH}), 128.63(\mathrm{CH}), 126.58(\mathrm{CH}), 122.08$ (CH), 83.61 (C). qNMR: 95.3\%.

\section{ASSOCIATED CONTENT}

\section{S Supporting Information}

The Supporting Information is available free of charge on the ACS Publications website at DOI: 10.1021/acs.jmedchem.7b01388.

Summary reporting all the synthesized compounds (Table S1); detailed synthetic procedures for 1-16 and corresponding intermediates; $\mathrm{H}$ NMR, C NMR, mass spectrometry, and chromatographic characterization of 1-16; summary of $1-16$ activity results (Table
S2); structural model of topoII (Figures S1, S2); docking poses of 1-5 (Figure S3); topoisomerase inhibition, topoisomerase poisoning, and ctDNA binding assays procedures; cell lines and cell viability assay description (PDF)

Molecular formula strings and additional experimental data (CSV)

\section{AUTHOR INFORMATION}

\section{Corresponding Authors}

*C.S.: phone, +39049 827571; e-mail, claudia.sissi@unipd.it. *M.D.V.: phone, +39 01071781 577; e-mail, marco.devivo@iit. it.

ORCID

Jose M. Arencibia: 0000-0003-3227-931X

Claudia Sissi: 0000-0002-9713-1415

Marco De Vivo: 0000-0003-4022-5661

\section{Author Contributions}

${ }^{\perp}$ J.A.O. and L.R. contributed equally.

\section{Notes}

The authors declare the following competing financial interest(s): One patent application protecting the class of compounds disclosed in this manuscript has been filed by the following authors: Marco De Vivo, Jose Antonio Ortega, Jose M. Arencibia, and Claudia Sissi.

\section{ACKNOWLEDGMENTS}

This work was supported in part by the Italian Association for Cancer Research (AIRC) through the "IG 18883" Grant and by Università degli Studi di Padova (Grant 60A04-7255). We thank Grace Fox for her proofreading and copyediting.

\section{ABBREVIATIONS USED}

TopoII, type II topoisomerase; DNA, deoxyribonucleic acid; DCM, dichloromethane; $\mathrm{MeOH}$, methanol; EtOAC, ethyl acetate; DMF, N,N-dimethylformamide; DMAP, 4- $(\mathrm{N}, \mathrm{N}$ dimethylamino)pyridine; $t_{\mathrm{R}}$, retention time

\section{REFERENCES}

(1) Deweese, J. E.; Osheroff, N. The DNA cleavage reaction of topoisomerase II: wolf in sheep's clothing. Nucleic Acids Res. 2009, 37, $738-748$.

(2) Deweese, J. E.; Osheroff, M. A.; Osheroff, N. DNA topology and topoisomerases. Biochem. Mol. Biol. Educ. 2009, 37, 2-10.

(3) Pommier, Y. Drugging topoisomerases: lessons and challenges. ACS Chem. Biol. 2013, 8, 82-95.

(4) Bailly, C. Contemporary challenges in the design of topoisomerase II inhibitors for cancer chemotherapy. Chem. Rev. 2012, 112, $3611-3640$

(5) Palermo, G.; Minniti, E.; Greco, M. L.; Riccardi, L.; Simoni, E.; Convertino, M.; Marchetti, C.; Rosini, M.; Sissi, C.; Minarini, A.; De Vivo, M. An optimized polyamine moiety boosts the potency of human type II topoisomerase poisons as quantified by comparative analysis centered on the clinical candidate F14512. Chem. Commun. 2015, 51, 14310-14313.

(6) Pommier, Y.; Leo, E.; Zhang, H.; Marchand, C. DNA topoisomerases and their poisoning by anticancer and antibacterial drugs. Chem. Biol. 2010, 17, 421-433.

(7) Pogorelčnik, B.; Perdih, A.; Solmajer, T. Recent developments of DNA poisons human DNA topoisomerase II $\alpha$ inhibitors as anticancer agents. Curr. Pharm. Des. 2013, 19, 2474-2488. 
(8) Pogorelčnik, B.; Perdih, A.; Solmajer, T. Recent advances in the development of catalytic inhibitors of human DNA topoisomerase II $\alpha$ as novel anticancer agents. Curr. Med. Chem. 2013, 20, 694-709.

(9) Riddell, I. A.; Agama, K.; Park, G. Y.; Pommier, Y.; Lippard, S. J. Phenanthriplatin acts as a covalent poison of topoisomerase II cleavage complexes. ACS Chem. Biol. 2016, 11, 2996-3001.

(10) Palermo, G.; Cavalli, A.; Klein, M. L.; Alfonso-Prieto, M.; Dal Peraro, M.; De Vivo, M. Catalytic metal ions and enzymatic processing of DNA and RNA. Acc. Chem. Res. 2015, 48, 220-228.

(11) Wu, C.-C.; Li, T.-K.; Farh, L.; Lin, L.-Y.; Lin, T.-S.; Yu, Y.-J.; Yen, T.-J.; Chiang, C.-W.; Chan, N.-L. Structural basis of type II topoisomerase inhibition by the anticancer drug etoposide. Science 2011, 333, 459-462.

(12) Fortune, J. M.; Osheroff, N. Merbarone inhibits the catalytic activity of human topoisomerase II $\alpha$ by blocking DNA cleavage. J. Biol. Chem. 1998, 273, 17643-17650.

(13) Dimaggio, J. J.; Warrell, R. P.; Muindi, J.; Stevens, Y.-W.; Lee, S. J.; Lowenthal, D. A.; Haines, I.; Walsh, T. D.; Baltzer, L.; Yaldaei, S.; Young, C. W. Phase I clinical and pharmacological study of merbarone. Cancer Res. 1990, 50, 1151-1155.

(14) Malik, U. R.; Dutcher, J. P.; Caliendo, G.; Lasala, P.; Mitnick, R.; Wiernik, P. H. Phase II trial of merbarone in patients with malignant brain tumors. Med. Oncol. 1997, 14, 159-162.

(15) Larsen, A. K.; Escargueil, A. E.; Skladanowski, A. Catalytic topoisomerase II inhibitors in cancer therapy. Pharmacol. Ther. 2003, 99, 167-181.

(16) Palermo, G.; Favia, A. D.; Convertino, M.; De Vivo, M. The molecular basis for dual fatty acid amide hydrolase (FAAH)/ Cyclooxygenase (COX) inhibition. ChemMedChem 2016, 11, 12521258.

(17) Favia, A. D.; Habrant, D.; Scarpelli, R.; Migliore, M.; Albani, C.; Bertozzi, S. M.; Dionisi, M.; Tarozzo, G.; Piomelli, D.; Cavalli, A.; De Vivo, M. Identification and characterization of carprofen as a multitarget fatty acid amide hydrolase/cyclooxygenase inhibitor. $J$. Med. Chem. 2012, 55, 8807-8826.

(18) Ranise, A.; Spallarossa, A.; Schenone, S.; Bruno, O.; Bondavalli, F.; Pani, A.; Marongiu, M. E.; Mascia, V.; La Colla, P.; Loddo, R. Synthesis and antiproliferative activity of basic thioanalogues of merbarone. Bioorg. Med. Chem. 2003, 11, 2575-2589.

(19) Cesarini, S.; Spallarossa, A.; Ranise, A.; Bruno, O.; Arduino, N.; Bertolotto, M.; Dallegri, F.; Tognolini, M.; Gobbetti, T.; Barocelli, E. 6-Amino-4-oxo-1,3-diphenyl-2-thioxo-1,2,3,4-tetrahydropyrimidine-5carbonyl derivatives as a new class of potent inhibitors of Interleukin8 -induced neutrophil chemotaxis. Bioorg. Med. Chem. 2009, 17, 35803587.

(20) Spallarossa, A.; Rotolo, C.; Sissi, C.; Marson, G.; Greco, M. L.; Ranise, A.; La Colla, P.; Busonera, B.; Loddo, R. Further SAR studies on bicyclic basic merbarone analogues as potent antiproliferative agents. Bioorg. Med. Chem. 2013, 21, 6328-6336.

(21) Kuhne, M.; Gallay, J. J. Thiobarbituric Acid Derivatives and Their Use as Anthelminthics. U.S. Patent US4670441A, 1987.

(22) De Vivo, M.; Masetti, M.; Bottegoni, G.; Cavalli, A. Role of molecular dynamics and related methods in drug discovery. J. Med. Chem. 2016, 59, 4035-4061.

(23) Docking calculations (Glide) were performed using PDB code 3QX3 (2.16 ̊ resolution; see ref 11). The grid for docking the compounds was centered at the centroid of nucleotides $T_{+1}$ and $G_{+5}$ whose bases enclose etoposide's aglycone core.

(24) Wilstermann, A. M.; Bender, R. P.; Godfrey, M.; Choi, S.; Anklin, C.; Berkowitz, D. B.; Osheroff, N.; Graves, D. E. Topoisomerase II-drug interaction domains: identification of substituents on etoposide that interact with the enzyme. Biochemistry 2007, 46, 82178225.

(25) Bender, R. P.; Jablonksy, M. J.; Shadid, M.; Romaine, I.; Dunlap, N.; Anklin, C.; Graves, D. E.; Osheroff, N. Substituents on etoposide that interact with human topoisomerase II $\alpha$ in the binary enzymedrug complex: contributions to etoposide binding and activity. Biochemistry 2008, 47, 4501-4509.
(26) Baviskar, A. T.; Amrutkar, S. M.; Trivedi, N.; Chaudhary, V.; Nayak, A.; Guchhait, S. K.; Banerjee, U. C.; Bharatam, P. V.; Kundu, C. $\mathrm{N}$. Switch in site of inhibition: a strategy for structure-based discovery of human Topoisomerase II $\alpha$ catalytic inhibitors. ACS Med. Chem. Lett. 2015, 6, 481-485.

(27) Huang, X.; Traganos, F.; Darzynkiewicz, Z. DNA damage induced by DNA topoisomerase I- and topoisomerase II-inhibitors detected by histone $\mathrm{H} 2 \mathrm{AX}$ phosphorylation in relations to the cell cycle phase and apoptosis. Cell Cycle 2003, 2, 613-618. 